Arab Univ. J. Agric. Sci., Ain Shams Univ., Cairo, 14(1), 491-507, 2006

\title{
SUSCEPTIBILITY OF SOME MANGO VARIETIES TO THE BUD MITE ERIOPHYES MANGIFERAE (SAYED) AND MAL- FORMATION DISEASE AND THE RELATION OF MITE INFESTATION TO MALFORMATION DISEASE
}

[33]

\author{
Mahgoob $^{1}$, A.E.A.
}

\begin{abstract}
In field study, Eleven mango varieties, (Mangiferae indica L.) at Sharkia, Ismailia, and Fayoum Governorates, were examined to estimate the population fluctuation of the bud mite Eriophyes mangiferae Sayed, their susceptibility to mite infestation, the relation between the mite infestation and chemical contents of mango buds and the correlation between the bud mite and malformation disease. The highest population occurred during Sept. to Jan. or Feb. and the lowest population was existed during Mar. to Jun. Temperature and relative humidity had no significant effect on the mite population. The highest level of mite infestation was recorded at Sharkia followed by Fayoum and Ismailia Governorates. Mango varieties were differed in their susceptibility to E. mangiferae infestation. Zebda, Taimour, Ewais and Arnaba were the most susceptible varieties, while Mabrouka, Company, Excellent Succari and White Succari were the least susceptible ones. On the other hand Mesk, Geolck and Alphonse varieties showed moderate susceptibility to mite infestation. Buds of some high susceptible varieties possessed a lower values of total carbohydrates and total soluble sugars than some moderate or susceptible varieties to mite infestation. Phenol contents recorded a higher levels in the most of susceptible varieties while a lower levels were found in the most of moderate and low susceptible varieties. The total soluble proteins and amino acids recorded a higher values in some susceptible varieties. The susceptible characteristic was positively correlated with total soluble proteins and amino acids while negatively correlated with the total carbohydrates and total soluble sugars. However the phenol content showed no clear trend. Obtained results also revealed that mango varieties had varying degrees of floral malformation, Company, Alphonse and Geolck were the most susceptible varieties, while Zebda var. was the most resistant one. Statistical analysis showed a negative correlation between the eriophid bud mite and the incidence of malformation disease. Zebda var. harboured the highest number of mites but exhibited the lowest percentages of malformation, whereas the opposite trend was observed with company var.
\end{abstract}

1- Department of Plant Protection, Faculty of Agriculture, Ain Shams University, Shoubra El-Kheima, Cairo, Egypt

(Received November 26, 2005)

(Accepted December 7, 2005) 
Key Words: Mango, Eriophyid, Eriophyes mangiferae, Chemical composition, Plant resistance, Malformation.

\section{INTRODUCTION}

During the few last decades mango plantations in Egypt, extended to cover wide areas of the new reclaimed lands. Arthropod pests are considered one of the factors limiting mango production, phytophagous mites are one of these pests. In Egypt, survey of phytophagous mites inhabiting different mango varieties revealed that the occurrence of Eriophyes mangiferae (Sayed), Vasates mangiferae (Attiah) and Oligonychus mangiferus (R. and S.). However A.. mangiferae was found to be the most important pest as it destroyed the inflorescences (Zaher and Osman 1970). E. mangiferae played a great role in the deterioration of mango trees and consequently producing a poor crop (Wafa et al 1970). The mango bud mites causes necrosis of the tender tissues. When mite population is high, the bud may be killed (Bindra and Bakhetia, 1971). Mango bud mite caused a sever damage to both old and young trees and considered a pest of economic importance in nurseries (Doreste, 1984). Moreover the bud mites one of the most important pests and consider to be the vector of the fungus Ceratocyctis fimbriata that causes die-back disease. (Yamashiro and Myazaki, 1985), and fungus Fusarium subglutinans [Gibberella fujkuroi var. subglutinans] the causal agent of mango malformation (Labuschagne et al 1993). Mango varieties are so varying to their susceptibility to eriophyid bud mite. (Kodirah 1969; Zaher \& Osman 1970; Wahba et al 1984 \& Suresh and Mo- hanasundaram, 1995). Many studies were done on the relationship between the mite or insect infestation and chemical contents of their host plants. (Atwa $\boldsymbol{e t}$ al 1987; Weibull 1988 and Zaki, 1991). Mango varieties had varying degree of floral malformation, however malformation of both floral and vegetative organs causes a deterioration of the trees as well as crop (Shawky \& Dahshan 1978; Wahba et al 1984 and Dahshan 1987a). Moreover, Ploetz et al (1999) mentioned that a significant impediment to increase mango production in Egypt is the malformation. Furthermore, mango malformation is an economically important disease of Mangifera indica globally (Britz et al 2002). Shibnath and Chakrabarti (1988) mentioned that differences in the amount of phenolic and steroidal compounds in healthy and malformed florets of $M$. indica, resulting from the hypersensitive responses in the host species to the fungal disease. Analysis of stem mango seedling showed that malformed plants contained approximately twice as much total nitrogen, protein, and amino acids as healthy plants (Singh et al 1989).

In the present investigation field study were carried out at Sharkia, Ismailia, and Fayoum Governorates where mango plantation are widespread in Egypt, to evaluate the population fluctuation of eriophyid bud mite $E$. mangiferae on the most important mango varieties, the susceptibility of them to mite infestation, the relation between the infestation and chemical contents and the correlation between the eriophyid bud mite and malformation disease. 


\section{MATERIAL and METHODS}

Mango varieties were chosen from three different locations represent different climatic conditions. Five trees from each mango variety were chosen under ordinary cultural practices. Each tree was considered as a replicate and a complete randomized plot desigen was followed. Six buds from each tree of each variety were monthly taken for counting the eriophid bud mite E. mangiferae during the period from Sept. 2002 till June 2003. The locations and mango varieties were as following:

\section{Locations}

\section{Mango varieties}

Sharkia (Abohamad Elsanagra)

Ismailia (FayedEldabeia)

Fayoum (IbshawaiSinaro)

Company, Goleck, Mesk and Arnaba

Alphonse, White Succri and Excellent Succri Alphonse, Taimour and Mabrouka

Ewais and Zebda varieties were sampled from all locations

\section{Counting the eriophyid bud mites}

The collected mango buds were dissected and examined by means of a dissecting microscope and the mites inside each bud were counted separately.

\section{Estimation of malformation}

Percentages of malformed flowers to the total number of flowers carried by each tree of each variety were calculated.

\section{Chemical Analysis}

A randomly mango buds from each mango varieties (except Excellent Succari) were collected at the beginning of the differentiation period (by the end of Feb. and the beginning of March) for chemical analysis.

\section{Determination of the following compo- nents}

\section{a. Total Carbohydrates}

One g sample of mango buds was taken and added to $30 \mathrm{ml} \mathrm{HCL} \mathrm{2N}$. The tubes were placed in a boiling water bath for $6 \mathrm{~h}$. After cooling, each sample was transferred into a calibrated flask (100$\mathrm{ml})$. Total carbohydrates was estimated by the alkaline potassium ferricyanide method (Shales and Schales, 1945).

\section{b. Total Soluble Sugars}

One g. sample of mango buds was ground in a mortar with ethanol $80 \%$ for 3 times. The extracts were combined and evaporated till dryness. The dried film was dissolved in $50 \mathrm{ml}$ of $10 \%$ aqueous isopropanol. Total soluble sugars determination was carried out according to the method of Shales and Schales (1945).

\section{c. Soluble Protein}

One g. sample was dried and mixed with $5 \mathrm{ml}$ of extraction buffer $(0.125 \mathrm{M}$ tris borate, ph 8.9) then shaked for one hour and filtered. The supernatant contained the soluble protein. A colorimetric determination of soluble protein was carried out by using the method of Bradford (1976). 


\section{d. Phenols}

\section{Extraction}

One g. fresh weight of buds was taken and extracted with $80 \%$ cold methanol (v/v) for three times at $0 \dot{\mathrm{C}}$. The combined extract was filtered (Wt. No. 1) and its volume was made up to $25 \mathrm{ml}$ with cold methanol.

\section{Analysis}

Phenols determination was carried out according to Daniale and George (1972). One $\mathrm{ml}$ extract was added to 0.5 ml Folin \& Ciocalteu's Phenol Reagent, shaken and allowed to stand for $3 \mathrm{~min}$. Then one ml saturated sodium carbonate $(25 \%, w / v)$ was added to each tube, followed by $10 \mathrm{ml}$ distilled water, shaken and allowed to stand for $60 \mathrm{~min}$. the optical density was determined at $730 \mathrm{~nm}$ using spectrophotometer (Shimadzu UV160A). Amount of total phenolic compound was calculated according to standard curve of pyrogallol (99.5\%) and expressed as equivalent microgram of pyrogallol per gram of fresh weight.

\section{f. Free Amino Acids}

Total amino nitrogen (free amino acids) was determined according to methods of Plummer (1978). Amino acids were extracted from $0.5 \mathrm{gm}$ fresh weight with $25 \mathrm{ml}$ hot $80 \%$ ethanol at $70 \dot{\mathrm{C}}$ for at least three times. The extracts were collected and evaporated to dryness at 55 $\dot{\mathrm{C}}$. The dried film was dissolved in $100 \mathrm{ml}$ of $10 \%$ aqueous isopropanol.

For assay, one $\mathrm{ml}$ of sample was pipetted out into a series of test tubes, and then total volume made up to $4 \mathrm{ml}$ with distilled water. One $\mathrm{ml}$ of ninhydrin reagent $(4 \%)$ was added to each tube, mixed well, and the tubes were kept in a boiling water bath for 15 minutes. Then the tubes were cooled and the volume was made up to $10 \mathrm{ml}$ in measuring flask with $50 \%$ ethanol. The pink color developed was measured using a Spectrophotometer (Spectronic 21) at $570 \mathrm{~nm}$ DL-isoleucin. The concentration of total amino nitrogen as DL-isoleucin was calculated from the standard curve.

\section{Statistical Analysis}

The collected data were subjected to the proper statistical analysis of complete randomized design according to procedure outlined by Snedecor and Cochran (1980). L. S. D. at 1 and 5\% level of probability was used to compare between means according to Waller and Duncan (1969). Simple correlation between the malformation percentages and number of mites existing buds of mango varieties was calculated. Also population estimation was correlated with temperature and relative humidity records available from Metrological Stations.

\section{RESULTS}

\section{Population fluctuation of eriophyid bud mite $E$. mangiferae}

The monthly population of E. mangiferae found inside the buds of different mango varieties at different locations under study are shown in Table (1) and Fig. (1)

\section{A. Effect of sampling period on the population fluctuation of $E$. man- giferae over all}

The highest average numbers of $E$. mangiferae were recorded during Oct., 
Dec. and Nov. (40.67, 40.61 and 40.42 mite/bud) respectively, followed by Sept. and Jan. (34.53 and $34.43 \mathrm{mite} / \mathrm{bud}$ ) respectively. While the lowest numbers were recorded during Apr., May and Jun. (5.94, 8.29 and $10.63 \mathrm{mite} / \mathrm{bud})$ respectively. A moderate number was recorded during Feb.

\section{B. Effect of mango varieties and the sampling period on the population fluctuation of $E$. mangiferae at dif- ferent locations}

The obtained data indicated that all different mango varieties were infested with E. mangiferae with a wide range of variations in numbers depending on mango varieties as well as sampling period. The maximum mean number of mites per bud of Ewais var. were (80.54, 70.42 and 46.06) during Jun., Nov. and Sept. while the lowest ones were $(2.08,3.85$ and 7.33) during May at Ismailia, Sharkia and Fayoum Governorates respectively. Zebda var. was on the same trend, the highest numbers of mites per bud were (81.02, 68.31 and 61.91) during Nov., Jan. and Nov. while the lowest ones were (3.57, 2.43 and 11.57) during Jun., May and Apr. at Sharkia, Ismailia and Fayoum Governorates respectively. Regarding to Alphonse var. the highest numbers of mite were recorded during Jan.(63.35) and Sept. (41.52) mite per bud, while the lowest ones were (6.75 and 1.70) mite per bud during May at Fayoum and Ismailia Governorates respectively.

Concerning the mango varieties which were sampled only from one location, the highest and the lowest numbers of mite were as fallowing, (71.79 and $1.81 \mathrm{mite} / \mathrm{bud}$ ) during Dec. and Mar. of Arnaba var.; (55.65 and 6.86 mite/bud) during Nov. and Feb. of Mesk var.; (41.49 and 6.25 mite/bud) during Jan. and Mar. of Goelck var. while (33.35 and 5.06 mite/bud) during Nov. and Apr. of Company var. respectively at Sharkia Governorate.

The highest and the lowest numbers of mite were (23.63 and $1.56 \mathrm{mite} / \mathrm{bud}$ ) recorded during Dec. and May respectively of Excellent Succri var., whereas (34.07 and 0.80 mite/bud) recorded during Jan. and Apr. respectively of White Succri at Ismilia Governorate. Similarly in Fayoum Governorate, Taimour var. harboured the highest number of mite (86.82 mite/bud) during Jan. On the other hand the maximum and minimum numbers of mite inhabited Mabrouka var. were (46.03 and 4.50 mite/bud) during Oct. and Apr. respectively.

\section{Effect of locations and the sampling period on the population fluctua- tion of $E$. mangiferae}

Comparative population fluctuation study of E. mangiferae, data presented in Table (1) and Fig. (1). revealed that the highest peaks of mite population occurred during the period of Sept. through Feb. whereas the lowest peaks occurred during the period of Mar. through Jun. at all locations. However the population density of mite infestation significantly was varied within months of each location as well as between the locations.

The highest and the lowest averages numbers of $E$. mangiferae inhabited mango buds ranged from (35.33 to 55.19 and 5.77 to $10.30 \mathrm{mite} / \mathrm{bud}$ ); (34.06 to 46.35 and 1.92 to $8.66 \mathrm{mite} / \mathrm{bud})$ and (32.34 to 36.8 and 8.61 to 13.23 mite/bud) at Sharkia, Ismailia and Fayoum Governorates during the period of 
Table 1. Fluctuation of the eriophyid bud mite, E. mangiferae infesting some different mango varieties at different locations in Egypt during the period from Sep. 2002 till Jun. 2003.

\begin{tabular}{|c|c|c|c|c|c|c|c|c|c|c|c|c|}
\hline \multirow[b]{2}{*}{ Location } & \multirow{2}{*}{$\begin{array}{c}\text { Mango } \\
\text { varieties }\end{array}$} & \multicolumn{11}{|c|}{ Mean No.of E. mangiferae / bud during the period from Sep. 2002 till Jun. 2003.} \\
\hline & & Sep.2002 & Oct. & Nov. & Dec. & Jan.2003 & Feb. & Mar. & Apr. & May & $\begin{array}{c}\text { Jun. } \\
2003 \\
\end{array}$ & Average \\
\hline \multirow{6}{*}{ Sharkia } & Ewais & 34.08 & 64.63 & 70.42 & 67.86 & 23.15 & 19.67 & 18 & 5.81 & 3.85 & 11.11 & $31.86 \mathrm{c}$ \\
\hline & Zebda & 54.68 & 75.21 & 81.02 & 80.65 & 21.63 & 14.32 & 13.19 & 6.59 & 7.86 & 3.57 & $35.87 \mathrm{a}$ \\
\hline & Company & 21.24 & 22.12 & 33.35 & 8.25 & 29.36 & 11.23 & 5.79 & 5.06 & 7.27 & 11.98 & $15.56 \mathrm{i}$ \\
\hline & Goeleck & 20.07 & 19.98 & 37.26 & 41.19 & 41.49 & 18.57 & 6.25 & 7.15 & 9.79 & 13.13 & $21.49 \mathrm{~g}$ \\
\hline & Mesk & 24.17 & 49.81 & 55.65 & 29.46 & 10.61 & 6.86 & 19.32 & 8.01 & 9.02 & 13.88 & $22.68 \mathrm{f}$ \\
\hline & Arnaba & 57.77 & 46.6 & 53.45 & 71.79 & 11.01 & 2.48 & 1.81 & 2.03 & 27.37 & 8.15 & $28.25 \mathrm{~d}$ \\
\hline \multirow{5}{*}{ Ismailia } & Ewais & 35.82 & 48.06 & 34.61 & 66.94 & 80.54 & 20.05 & 9.79 & 5.84 & 2.08 & 11.06 & $31.48 \mathrm{c}$ \\
\hline & Zebda & 44.65 & 56.98 & 38.92 & 56.62 & 68.31 & 22.11 & 19.34 & 6.37 & 2.43 & 15.62 & $33.13 b$ \\
\hline & Alphonse & 41.52 & 41.2 & 24.76 & 27.32 & 32.54 & 8.96 & 6.86 & 2.48 & 1.7 & 7.61 & $19.49 \mathrm{~h}$ \\
\hline & Excellent Succari & 22.66 & 19.47 & 19.75 & 23.67 & 16.27 & 14.19 & 4.64 & 1.86 & 1.57 & 5.12 & $12.92 \mathrm{j}$ \\
\hline & White Succri & 25.66 & 27.29 & 23.79 & 32.54 & 34.07 & 8.31 & 2.66 & 0.8 & 1.84 & 3.33 & $16.03 \mathrm{i}$ \\
\hline \multirow{5}{*}{ Fayoum } & Ewais & 46.06 & 40.1 & 43.87 & 29.88 & 23.76 & 20.52 & 16.46 & 9.5 & 7.33 & 21 & $25.85 \mathrm{e}$ \\
\hline & Zebda & 16.61 & 28.56 & 61.91 & 45.12 & 28.28 & 37.81 & 16.37 & 11.57 & 19.53 & 16.93 & $28.27 \mathrm{~d}$ \\
\hline & Alphonse & 20.34 & 20.62 & 30.94 & 28.75 & 63.35 & 11.04 & 9.57 & 6.75 & 13.3 & 10.86 & $21.55 \mathrm{~g}$ \\
\hline & Taimour & 43.3 & 44.11 & 22.34 & 26.34 & 53.79 & 86.82 & 18.87 & 10.72 & 10.81 & 10.52 & $32.76 \mathrm{bc}$ \\
\hline & Mabrouka & 43.87 & 46.03 & 14.59 & 13.33 & 12.72 & 5.52 & 4.86 & 4.5 & 6.98 & 6.17 & $15.86 \mathrm{i}$ \\
\hline \multirow{4}{*}{ Average } & Over all & $34.53 \mathrm{~B}$ & $40.67 \mathrm{~A}$ & $40.42 \mathrm{~A}$ & $40.61 \mathrm{~A}$ & $34.43 \mathrm{~B}$ & $19.28 \mathrm{C}$ & $10.86 \mathrm{D}$ & $5.94 \mathrm{~F}$ & $8.29 \mathrm{E}$ & $10.63 \mathrm{D}$ & 24.57 \\
\hline & Sharkia & 35.33 & 46.39 & 55.19 & 49.87 & 22.87 & 12.19 & 10.73 & 5.77 & 10.86 & 10.3 & $25.95 \mathrm{~A}$ \\
\hline & Ismailia & 34.06 & 38.6 & 28.37 & 41.42 & 46.35 & 14.72 & 8.66 & 3.47 & 1.92 & 8.55 & $22.61 \mathrm{C}$ \\
\hline & Fayoum & 34.04 & 35.88 & 34.73 & 28.68 & 36.38 & 32.34 & 13.23 & 8.61 & 11.59 & 13.1 & $24.86 \mathrm{~B}$ \\
\hline
\end{tabular}

Means with the same litter within each column or row are not significantly different

LSD

$\begin{array}{cc}0.05 \% & 0.01 \% \\ 0.88 & 1.16 \\ 1.12 & 1.47 \\ 3.53 & 4.63 \\ 0.55 & 0.73 \\ 1 & 1.32 \\ 1.12 & \\ 1.36 & \\ 2.07 & \end{array}$

Arab Univ. J. Agric. Sci., 14(1), 2006 


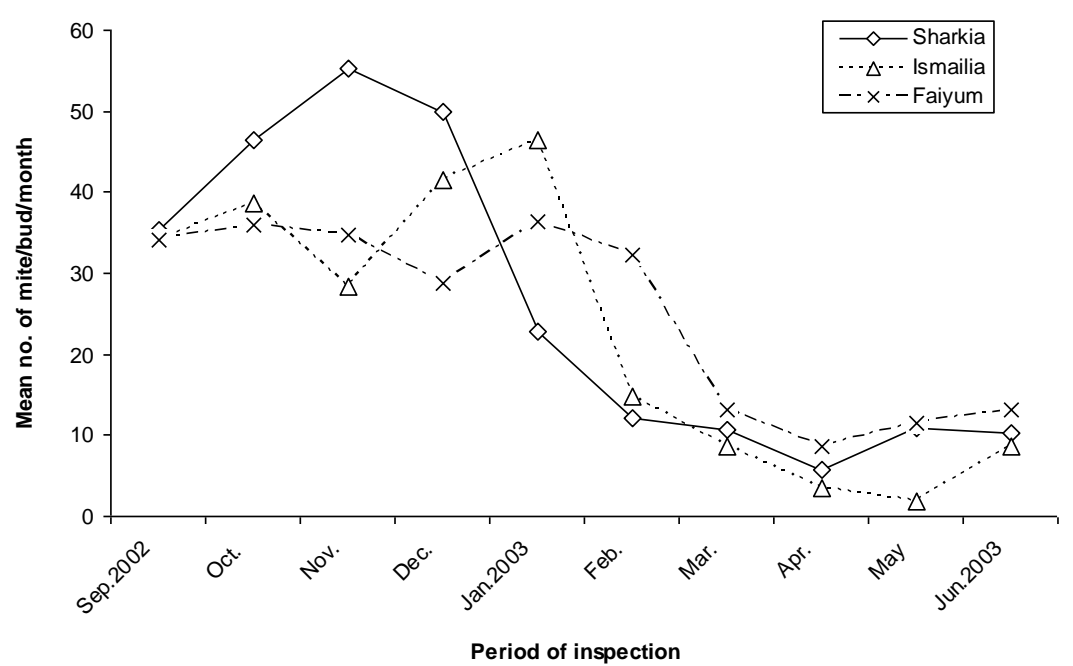

Fig. 1. Population fluctuation of E. mangiferae on mango cultivars at Sharkia, Ismailia and Faiyum Governorates during the period from Sept. 2002-Jun. 2003

Sept. through Feb. and Mar. through Jun. respectively.

\section{Effect of temperature and relative humidity on the population fluctua- tion of $E$. mangiferae}

Statistical analysis showed that a negative correlation $(\mathrm{r}=-0.002$ and -0.003$)$ was found between the mite population and degrees of temperature at Sharkia and Fayoum Governorates, while a slightly positive correlation $(\mathrm{r}=0.6)$ at Ismailia Governorate. A negative correlation ( $\mathrm{r}=$ 0.4 ) also was found between the mite population and the relative humidity at Ismailia Governorate, on the other hand a slightly and strongly positive correlation $(\mathrm{r}=0.6$ and 0.8$)$ at Sharkia and Fayoum Governorates respectively. However regardless the locations, correlation between the mite population and degrees of temperature $\&$ relative humidity were $(\mathrm{r}=$ 0.2 and -0.1 ) respectively.

\section{Levels of the bud mite infestation of mango varieties at different loca- tions}

The highest level of mite infestation was recorded at Sharkia Governorate with an average of $25.95 \mathrm{mite} / \mathrm{bud}$, followed by Fayoum and Ismailia Governorates with an averages of 24.86 and 22.61 mite/bud respectively (Table 1).

\section{Susceptibility of different mango varieties to $E$. mangiferae. infesta- tion}

Statistical analysis showed occurrence of highly significant differences between the mango varieties to mite infestation. However Zebda, Taimour, Ewais and Arnaba varieties were more susceptible, the average number of mite per bud were (35.87, 32.76, 31.86 and 28.25) respectively. While Excellent Succari, White 
Succari, Mabrouka and Company varieties were more resistant, the average numbers of mite per bud ranged from (12.92 to 15.56). On the other hand Alphonse, Geolck and Mesk varieties were moderate in their susceptibility, the average number of mite per bud ranged from (19.49 to 22.68). It is worth noting that Zebda and Ewais varieties are the most susceptible ones of all locations.

\section{Chemical constituents of mango buds}

Data in Table (2) revealed that the different mango varieties were significantly varied in their bud chemical compositions. The obtained results could be summarized as following.

\section{Total carbohydrates}

The highest values of total carbohydrates were found in the buds of Mesk, Company and Mabrouka varieties (42.72, 40.07 and $38.58 \mathrm{mg} / \mathrm{g}$ ) respectively. While the lowest values were recorded in White Succri var. (28.07 mg/g) and Zebda var. $(18.81 \mathrm{mg} / \mathrm{g})$.

\section{Soluble Sugars}

Total soluble sugars concentrations recorded markedly the highest levels in the buds of Alphonse, White Succri varieties (71.22 and $60.45 \mathrm{mg}$ ) respectively. Whereas the lowest concentrations ranged from (39.20 to $43.38 \mathrm{mg} / \mathrm{g}$ ) of Mabrouka, Taimour, Arnaba and Company varieties.

\section{Phenol content}

The buds of White Succari, Arnba, Zebda and Alphonse varieties contained a highly significant levels of phenolic contents which averaged between (2.31 to $2.48 \mathrm{mg} / \mathrm{g}$ ). On the other hand, the lowest level $(1.82 \mathrm{mg} / \mathrm{g})$ was recorded in Mesk var.

\section{Free amino acids}

The highest concentrations of free amino acids were (1.09 and $0.85 \mathrm{mg} / \mathrm{g}$ ) recorded in the buds of Arnaba and Mesk varieties. Whereas the lowest levels were averaged between $(0.28$ to $0.33 \mathrm{mg} / \mathrm{g})$ found in Company, Ewais and Taimour varieties.

\section{Soluble proteins}

The soluble proteins recorded a high values averaged between (3.94 to 4.26 $\mathrm{mg} / \mathrm{g}$ ) in the buds of most mango varieties under study. However the lowest value was $(3.35 \mathrm{mg} / \mathrm{g})$ of Company var. The mango varieties of Ewais, Zebda, and Alphonse located in different Governorates showed a slightly differences or may be not in their chemical contents under investigation.

\section{Severity of malformation related to mite infection}

As shown in Table (3) percentage of floral malformation was the highest in Company var. (36.60\%) at Sharkia governorate, followed by Alphonse var. $(29.00 \%)$ at Ismailia Governorate and Geolck var. (25.40 \%) at Sharkia Governorate. The lowest percentage of malformation was observed in Zebda var. ranged from $(1.80 \%$ to $3.84 \%)$ at all locations, followed by Mabrouka var. $(8.80 \%)$ at Fayoum Governorate and White Succari $(11.80 \%)$ at Ismailia 
Table 2. Chemical composition of the vegetative buds of some different mango varieties at different locations in Egypt.

\begin{tabular}{|c|c|c|c|c|c|c|}
\hline \multirow[b]{2}{*}{ Location } & \multirow{2}{*}{$\begin{array}{c}\text { Mango } \\
\text { varieties }\end{array}$} & \multicolumn{5}{|c|}{ Chemical composition of mango buds mg/g of F. W. } \\
\hline & & $\begin{array}{c}\text { Total } \\
\text { Carbohy- } \\
\text { drates }\end{array}$ & $\begin{array}{c}\text { Total } \\
\text { soluble } \\
\text { sugars }\end{array}$ & $\begin{array}{l}\text { Phenols } \\
\text { Phenols }\end{array}$ & $\begin{array}{c}\text { Free } \\
\text { amino } \\
\text { nacids }\end{array}$ & $\begin{array}{l}\text { Soluble } \\
\text { proteins }\end{array}$ \\
\hline \multirow{6}{*}{ Sharkia } & Ewais & $34.94 \mathrm{e}$ & 48.18de & $2.06 \mathrm{~d}$ & $0.63 \mathrm{c}$ & $3.99 \mathrm{abcd}$ \\
\hline & Zebda & $18.81 \mathrm{i}$ & $47.26 f$ & $2.39 \mathrm{ab}$ & $0.33 \mathrm{~h}$ & $3.58 \mathrm{e}$ \\
\hline & Company & $40.07 \mathrm{~b}$ & $43.38 \mathrm{~h}$ & $2.12 \mathrm{~d}$ & $0.28 \mathrm{i}$ & $3.35 \mathrm{e}$ \\
\hline & Goeleck & $37.96 \mathrm{~d}$ & $49.58 \mathrm{c}$ & $2.12 \mathrm{~d}$ & $0.59 \mathrm{cde}$ & 4.16abc \\
\hline & Mesk & $42.72 \mathrm{a}$ & $46.18 \mathrm{~g}$ & $1.82 \mathrm{e}$ & $0.85 b$ & $3.86 \mathrm{~cd}$ \\
\hline & Arnaba & $30.47 \mathrm{~h}$ & $41.86 \mathrm{i}$ & $2.47 \mathrm{a}$ & $1.09 \mathrm{a}$ & $3.94 \mathrm{bcd}$ \\
\hline \multirow{4}{*}{ Ismailia } & Ewais & $35.07 \mathrm{e}$ & $48.42 \mathrm{~d}$ & $2.09 \mathrm{~d}$ & $0.6 \mathrm{~cd}$ & $4.05 \mathrm{abcc}$ \\
\hline & Zebda & $19.17 \mathrm{j}$ & $47.7 \mathrm{ef}$ & $2.18 \mathrm{~cd}$ & $0.37 \mathrm{gh}$ & $3.84 \mathrm{~d}$ \\
\hline & Alphonse & $33.15 f$ & $70.92 \mathrm{a}$ & $2.31 b c$ & $0.54 \mathrm{e}$ & $3.96 \mathrm{bcd}$ \\
\hline & White Succri & $28.07 \mathrm{i}$ & $60.45 b$ & $2.48 \mathrm{a}$ & $0.41 \mathrm{fg}$ & $4.22 \mathrm{ab}$ \\
\hline \multirow{5}{*}{ Fayoum } & Ewais & $35.07 \mathrm{e}$ & $48.42 \mathrm{~d}$ & $2.09 \mathrm{~d}$ & $0.6 \mathrm{~cd}$ & $4.05 \mathrm{abcc}$ \\
\hline & Zebda & $19.17 \mathrm{j}$ & $47.7 \mathrm{ef}$ & $2.18 \mathrm{~cd}$ & $0.37 \mathrm{gh}$ & $3.84 \mathrm{~d}$ \\
\hline & Alphonse & $32.98 \mathrm{f}$ & $71.22 \mathrm{a}$ & $2.35 \mathrm{ab}$ & $0.55 \mathrm{de}$ & $3.99 \mathrm{abcc}$ \\
\hline & Taimour & $31.39 \mathrm{~g}$ & $40.28 j$ & $2.47 \mathrm{a}$ & $0.37 \mathrm{gh}$ & $4.26 \mathrm{a}$ \\
\hline & Mabrouka & $38.58 \mathrm{c}$ & $39.2 \mathrm{k}$ & $2.04 d$ & $0.44 \mathrm{f}$ & $4.18 \mathrm{ab}$ \\
\hline
\end{tabular}

Means with the same litter withen each column are not significantly different

LSD

$\begin{array}{llllll}0.05 \% & 0.56 & 0.49 & 0.14 & 0.05 & 0.26 \\ 0.01 \% & 0.75 & 0.66 & 0.19 & 0.07 & 0.34\end{array}$


Table 3. The relationship between the number of E. mangiferae and the malformation percentage of differen mango varieties at different locations in Egypt during the period from Sept. 2002 till Jun. 2003.

\begin{tabular}{|c|c|c|c|}
\hline \multirow[b]{2}{*}{ Locations } & \multirow{2}{*}{$\begin{array}{c}\text { Mango } \\
\text { varieties }\end{array}$} & \multicolumn{2}{|c|}{ Average No. of } \\
\hline & & $\begin{array}{l}\text { A. mangiferae/ bud/ } \\
\text { month }\end{array}$ & Malformation \% \\
\hline \multirow{6}{*}{ Sharkia } & Ewais & 31.86 & $21.4 \mathrm{~cd}$ \\
\hline & Zebda & 35.87 & $3.84 \mathrm{~g}$ \\
\hline & Company & 15.56 & $36.6 a$ \\
\hline & Goeleck & 21.49 & $25.4 \mathrm{bc}$ \\
\hline & Mesk & 22.68 & $15.4 \mathrm{de}$ \\
\hline & Arnaba & 28.25 & $21.2 \mathrm{~cd}$ \\
\hline \multirow{5}{*}{ Ismailia } & Ewais & 31.48 & $17.8 \mathrm{de}$ \\
\hline & Zebda & 33.13 & $2 \mathrm{~g}$ \\
\hline & Alphonse & 19.49 & $29 b$ \\
\hline & White Succri & 16.03 & $11.8 \mathrm{ef}$ \\
\hline & Excellent Succri & 12.92 & $16.4 \mathrm{de}$ \\
\hline \multirow{5}{*}{ Fayoum } & Ewais & 25.85 & $15.2 \mathrm{de}$ \\
\hline & Zebda & 28.27 & $1.8 \mathrm{~g}$ \\
\hline & Alphonse & 21.55 & $15.4 \mathrm{de}$ \\
\hline & Taimour & 32.76 & $17.4 \mathrm{de}$ \\
\hline & Mabrouka & 15.86 & $8.8 \mathrm{f}$ \\
\hline
\end{tabular}

Means with the same litter are not significantly different

LSD $0.05 \%$

Correlation

$r=-0.4$

Governorate. On the other hand, the malformation percentage was varied significantly between the same varieties at different locations.

Regarding to the relationship between the malformation disease and E. mangiferae. Statistical analysis showed a negative correlation $(-0.4)$ between both of them. However it is worth noting that Zebda var. harboured the highest numbers of mite but exhibited the lowest percentage of malformation, whereas the opposite trend was observed with company var. 


\section{DISCUSSION}

Tracing the normal distribution of $E$. mangiferae throughout the period from Sept. 2002 to Jun. 2003, the obtained results in Table (1) clearly revealed that peaks of this pest population occurred during the period from Sept. to Jan. or Feb. and the lowest population existed during Mar. to Jun. of all mango varieties at all different locations. Moreover the temperature and relative humidity had no significant effect on the mite population. However this finding strongly supported the obtained results by (Kodirah 1969; Zaher \& Osman 1970 and Wahba et al 1984).

Regarding to the differences between the mite population during the different seasons. Sawires et al (1989) and Zaki (1991) stated that the highest existence of tetranychid and tenuipalpid mites on citrus and stone fruit trees were mainly observed throughout Spring, Summer and Autmun than in Winter. Similar observation was recorded by Zaher and Osman (1970) to the Oligonychus mangiferus (R. and S.) and the eriophid mites Vasates mangiferae (Attiah) on mango leaves. Those authors attributed the higest existence of phytophagous mites to the abundant values of nutritional components, also the hot and warm weathers which necessary to mite propagation during these seasons. However this could be agree with our finding in the Autumn but totally disagree during the Winter. On the other hand Kodirah (1969) found the density of mango eriophyid bud mite $E$. mangiferae is more correlated with the state of buds whether are closed or open than averages of temperature or relative humidity, this strongly supported our results.
The research effort expanded to elucidate the problems of resistance to Acari is increasing, mostly in the case of spider mite (Karban and English 1988). In spite of growing economic importance of damage done by some eriophyid mites, only is known about resistance to these phytophagous mites (Westphal et al 1996). However in the present study data in Table (1) illustrated that mango varieties were differed in their susceptibility to E. mangiferae infestation. Zebda, Taimour and Ewais were the most susceptible varieties followed by Arnaba Var. while Mabrouka, Company, excellent Succari and White Succari were the least susceptible ones. On the other hand Mesk, Geolck and Alphonse varieties were moderate susceptibility of mite infestation. The aforementioned results confirmed by (Kodirah 1969; Zaher \& Osman 1970 and Wahba et al 1984) who reported that Zebda and Taimour varieties were the most susceptible, Hindi, Company and Bezrah varieties were moderate while Mabrouka, Romance, Dabsha and KalbEltour were the least in their susceptibility to mite infestation.

The chemical contents of the host plants are known to have some effect on the phytophagous arthropods therefore play an important role in plant defense. Data in Table (2) revealed that buds of Zebda and Ewais (high susceptible varieties) possessed a lower values of total carbohydrates and total soluble sugars than Mesk and Alphonse (moderate susceptible varieties) or Company, White Succari and Mabrouka (the lowest susceptible varieties) of mite infestation. The present results contradict with the finding of Atwa et al (1987) who found that total carbohydrates positively correlated with the period of immature and fecundity of 
female of some tetranychid mites. Moreover Chen et al (1996), found that reducing sugar content was lower in resistant tea cultivars than susceptible ones against to pink tea rust mite. On the other hand, phenol contents recorded a higher levels in the most of susceptible varieties (Taimour, Ewais and Arnaba), while a lower ones recorded in the most moderate and low susceptible varieties (Goeleck, Mesk, Company and Mabrouka). The previous results agree with the finding of Mahgoob (2004) who found that Citrus aurantifolia contained a higher concentration of phenols but susceptible to Tetranychus urticae Koch but Duranta. pulmieri and Pittosporum tobira contained lower content of phenols but resistant to the same mite. However differences in some phenolic compounds have been reported between Ribes varieties known to be resistant or susceptible to the gall mite Cecidophyopsis ribis (Westw.) (Herr, 1987 and 1988). The total soluble proteins and amino acids recorded the highest values in some susceptible varieties (Taimour and Arnaba), followed by the White Succari var. (low susceptible) and Mesk var. (moderate susceptible). Similar results were recorded by Swaires et al (1989) who found that the mite infestation of citrus trees were positively correlated with protein and nitrogen content, also Atwa et al (1987) reported that amino acids were positively correlated with the period of immature and fecundity of female Tetranychus urticae Koch and Eutetranychus annecki Meyer. However Weibull (1988) suggested that the concentration and composition of amino acids are factors that mediate aphid resistance in the plant genotypes and restrict the host plant range of aphids. The previous results revealed that mite infes- tation positively correlated with total soluble proteins and amino acids and negatively with total carbohydrates and total soluble sugars. However phenol content had no clear effect except in the variety of White Succari (low susceptible).

The present investigation obviously revealed that mango varieties had varying degrees of floral malformation, Company, Alphonse and Geolck varieties were the most susceptible, while Zebda var. was the most resistant. However the other varieties were moderate in their susceptibly. The previous observation strongly supported by the finding of Shawky \& Dahshan (1978); Wahba et al (1984) and Dahshan (1987b), who found that Hindi be Sinnara, Dabsha and Taimour varieties are highly susceptible, while Zebda var. proved to be most resistant one, but Ewais moderate Susceptible. Furthermore Sanjay et al (1994 and 1999) mentioned that forty two mango germplasm lines and 20 mango varieties were examined and none were found to be free from floral malformation.

Statistical analysis showed a negative correlation between the eriophyid bud mite and the incidence of malformation disease. However it is worth noting that Zebda var. harboured the highest numbers of mite but exhibited the lowest percentages of malformation, whereas the opposite trend was observed with company var. The obtained results suggested that this mite cannot be incriminated as the sole causative agent of this phenomenon, similar observation found by Wahba et al (1984) and strongly supported by Labuschagne et al (1993) who mentioned that the fungus Fusarium subglutinans [Gibberella fujkuroi var. subglutinans] was isolated from plant tissues and mites, and in turn used as an inocu- 
late. The results confirmed, Gibberella fujkuroi var. subglutinans as the causal agent of mango malformation. Although it was shown that E. mangiferae can serve as a vector for fungus. It was not improved that the presence of mite increased the incidence of malformation. However the etiology of mango malformation has been controversial and has been attributed to bacteria, viruses, phytoplasm, eriophyid mites (E. mangiferae) and physiological factors. Although information on many aspects remains inconclusive, most evidence points to the fungus Fusarium moniliforme [Gibberella fujikuroi] var. subglutinans as a causal agent (Salzar 1995 and Sant et al 1999). Finally an effective control of the eriophyid bud mite should, therefore, ensure better growth of mango trees and may in addition, reduce the incidence of malformation or at least restrict its spread if the mite acting as vector.

\section{ACKNOWLEDGEMENT}

The author would like to express his gratitude to Prof. Dr. Assem Shaltout (Dept. of Horticulture, Fact. Of Agric. Ain. Shams Univ.) for his helpful suggestions throughout this investigation and Prof. Dr. Samir . El-Deeb (Dept. Plant Pathology, Fact. Of Agric. Ain. Shams Univ.), for his assistance to estimate the percentages malformation disease of mango trees. Financial support provided by the project entitled "National Program for Promoting the Productivity and Exportability of Some Horticulture Crops" Coordinated, financed by French Food Aid Counterpart Fund (BLAFE), is greatly appreciated.
Atwa, Wedad, A.; Hoda, E. Abdel All and Ekram, A. Afify (1987). Influence of host plant species on the biology of Eutetranychus annecki Meyer and Tetranychus urticae Koch (Acari: Tetranychidae). Annals Agric. Sci. Ain Shams Univ. 32 : 799 - 809.

Bindra, O.S. and D.R.C. Bakhetia (1971). Studies on the chemical control of mango bud-mite Eriophyes mangiferae Sayed. Bull. Ent. Soc. Egypt. 55: 257271.

Bradford, M.M. (1976). A rapid and sensitive method for the quantitation of microgram quantities of protein utilizing the principal of protein-dye binding. Anal Biochem. 72: 248-254.

Britz, H.; E.T. Steenkmp; T.A. Coutinho; B.D. Wingfield; W.F.O. Marasas and M.J. Wingfield (2002). Two new species of Fusarium section Liseola associated with mango malformation. Mycologia. 94 : 722 - 730.

Chen, H.; N. Xu; X. Chen; Z. Chen and F. Yu. (1996). On the resistance mechanisms of tea clones to pink tea rust mite. Acta Phytophylacia Sinica. 23:137142.

Dahshan, D.I. (1987a). Physiological studies on malformation of mango panicles. Annals Agric. Sci. Ain Shams Univ., Cairo, 32: 565 - 575.

Dahshan, D.I. (1987b). Mango malformation: a new approach to causality. $\boldsymbol{A n}$ nals Agric. Sci. Ain Shams Univ., Cairo, $32: 1875$ - 1881.

Danial, H.D. and C.M. George (1972). Peach seed dormancy in relation to indogenous inhibitors and applied growth substances. J. Am. Soc. Hort. Sci. 17: 651-654.

\section{REFERENCES}


Doreste, S.E. (1984). Information on the mango eriophyid Eriophyes mangiferae (Sayed), in Venezuela. Revista de la Facultad de Agronomia Universidad Central de Venezuela. 13: 94 - 100.

Herr, R. (1987). Investigations into resistance mechanisms of the genus Ribs against the gall mite Cecidophyopsis ribis. In: Labeyrie V.; G. Fabres and D. Lachaise. Insect Plants. PP. 277-282. Junk Publishers, Dorddrecht, The Netherlands.

Herr, R. (1988). Untersuchngen zu, Resistenzmechanismus der Gattung Ribes gegen die johannisbeergallmilbe $\mathrm{Ce}$ cidophyopsis ribis. Mitteilungen Deutshe Gesellschaft Rur allgemeine angewandte Entomologie. 6: $17-21$.

Karban, R. and G. M. L. English (1988). Effects of herbivory and plant conditioning on the population dynamics of spider mites. Exp. Appl. Acarol. 4: 22-246.

Kodirah, S.M. (1969). Studies on Floral and Vegetative Malformation of Mango Trees and its Relationship with Aceria mangiferae Infestation. pp. 70-81. M.Sc. Thesis. Fac. Agric. Ain Shams Univ., Cairo.

Labuschagne, T.I.; M.H. Joubert and A. Steyn (1993). Role of the mango bud mite, Eriophyes mangiferae (Sayed) in mango malformation. Inligtingsbullwtin Instituut vir Tropiese Subtropiese Gewasse. 246: 19-24.

Mahgoob, A.E.A. (2004). Effect of chemical constituents and anatomical structure of some host plant leaves on twospotted spider mite. $\mathbf{9}^{\text {th }}$ Conf. Agric. Dev. Res., Fac. Agric., Ain Shams Univ., Cairo, Egypt, 2: 593-611.

Ploetz, R.C.J.L. Haynes; A. Vazquez and M.A.A. Sattar (1999). A preliminary study on the causal agent of mango malformation in Egypt. (Abstract). Phytopathology, 89: S60.

Plummer, D. T. (1978). An Introduction to Practical Biochemistry. pp. 174-175 \& pp. 183-184. McGraw-Hill Book Company(UK) Limited . London. New York.

Salazar, G.S. (1995). Mango malformation: a review. Revista Mexicana de Fitopatologia.13: 64-75.

Sanjay, S.; B.N. Sengupta; N. Roychoudhary and S. Singh. (1994). Studies on intensity and susceptibility to floral malformation of some important mango cultivars. Horticultural Journal. 7:97101.

Sanjay, S.; G.S. Yadav and S. Singh (1999). Studies on intensity and susceptibility to floral malformation in different mango germplasm. Orissa Journal of Horticulture. 27: 43-47.

Sant, R.; V.K. Yadav and S. Ram (1999). Mango malformation-a review. Journal of Applied Horticulture Lucknow 1: 70-78.

Sawires, Z.R.; F.K. Wl-Duweini and S.M. Ibrahim (1989). Ecological studies on phytophagous mites associated with different citrus trees in upper and lower Egypt. $3^{\text {rd }}$ Nat. Conf. of Pests and Dis. Of Veg. and Fruits in Egypt and Arab Count. Ismailia, Egypt.: 1011-1017.

Shales, O. and S.S. Schales (1945). A simple method for the determination of glucose in blood. Arch. Biochem. 8: 285 .

Shawky, I. and D.I. Dahshan (1978). Susceptibility of some mango cultivars to flowering malformation. Annals Agric. Sci. Ain Shams Univ. 23 : 147-152.

Shibnath, G. and D.K. Chakrabarti. (1988). Differences in phenolic and steroidal constituents between healthy and infected florets of Mangifera indica. Phytochemistry, 27: 1339-1343. 
Singh, Z.; B.S. Dhillon and Z. Singh (1989). Nitrogen, protein content and amino acid composition of malformed and healthy seedlings of mango. Acta Horticulture. 231: 878-882.

Snedecor, G.W. and W.G. Cochran (1980). Statistical Methods. $7^{\text {th }}$ Ed. pp. 264-267, Iowa State Univ. Press, Ames., Iowa, USA.

Suresh, S. and M. Mohanasundaram. (1995). Susceptibility of mango varieties to the bud mite Eriophyes mangiferae. Madras Agricultural Journal. 82: 666669.

Wafa, A.K.; M.A. Zaher and A.A. Osman (1970). Control of Phytophagous mites on mango trees in U.A.R. Bull. Ent. Soc. Egypt. 54: 219 - 225.

Wahba, M. L.; M.A. El- Enany and A.M. Farrag (1984). Five mango varieties as affected by malformation phenomenon and bud mite infestation in Egypt. Agricultural Research Review, 62: 141147.

Waller, R.A. and D.B. Duncan (1969). A bayes rule for the symmetric multiple comparison problem. J. Amer. Statistical Assoc., 64: 1485-1503.

Weibull, J. (1988). Free amino acid in the phloem sap from oats and barley resistant to Rhopalosiphum padi. Phytochememistry 27: 2069-2072.

Westphal, E.; R. Bronner and F. Dreger. (1996). Hostplant resistance. In: Lindquist, E.E.; M.W. Sabelis and J. Bruin. Eriophyoid Mites - Their biology, Natural Enemies and Control. pp. 681688. Elsevier Science, Amsetrdam, Netherlands.

Yamashiro, T. and I. Myazaki (1985). Principal pests and diseases of mango Mangifera indica L. in the State of Sao Paulo and updated control methods. Biologico. 51: $41-50$.

Zaher, M.A. and A.A. Osman (1970). Population studies on mites associated with mango trees in Egypt. Bull. Ent. Soc. Egypt. 54: 141-148.

Zaki, A.M. (1991). Chemical composition of stone fruit tree foliages and their role in tetranychid and tenuipalpid mites occurrence. Minufiya J. Agric. Res. 16: $877-885$. 


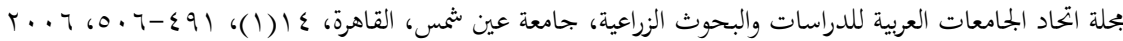

عriophyes mangiferae حساسية بعض أصناف المانجو لحم البراعم ومرض التشوة وعلاقة الإصابة بالحلم بمرض التشوة (Sayed)

$[r r]$

\section{أحمد عيا عبد المجيد محجوب'}

1 - قسم وقاية النبات - كلية الزراعة - جامعة عين شمس - شبرا الخيمة- القاهرة - مصر

-

$$
\text { تيمور - عويس- مبروكة الحئة }
$$

- أصناف متوسطة الحساسية :- مسك-

$$
\text { جوللك - ألفونس. }
$$

- أصناف قلبلة الحساسية :- كوبانية -

$$
\text { سكرى ممتاز - سكرى أبيض. }
$$

r- أحتوت بعض الأصناف شديدة الحساسية أليض

$$
\text { على مستوى منخفض من الكنون الكربوهيدرات }
$$

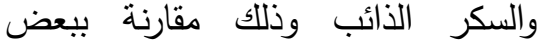
الأصناف منوسطة الحساسية أوالأصناف

$$
\text { قليلة الحساسية. }
$$

- أحتوت بعض الأصناف عالية الحساسية على مستوى عالى من الفينولات بينما معظم الاصناف متوسطة ومنخفضة الحساسية على مستوى منخض من هذة

$$
\text { الفينولات. }
$$

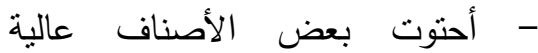
الحساسية على مستوى عالى من الإنى

البروتين الذائب والأحماض الأمينية. - أرتبطت شدة الأصابة بالحلم بزيادة الأبنة

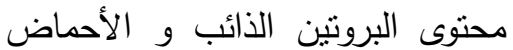
الأمينية فى الأصناف شديدة الحساسية.
فى دراسة حقلية خلال الفترة من سبتمبر

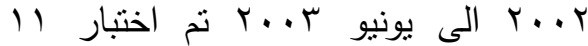
صنف من المانجو توجد في محافظات الثرقية-الاسماعيلية والفيوم وذللك لدراسة تذبذب تعداد الحلم عليها خلال هذة الفترة،

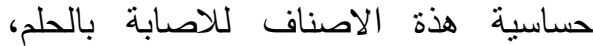
تأثنير التركيب الكيماوى للبراعم الخضرية على لاصنى

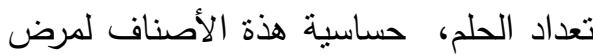
التشوة وكذلك علاقة مرض التشوة بتعداد الحلم. وكانت النتائج المتحصل عرضل عليها

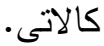
1- كان أعلى تعداد للحلم خلال الفترة من سبتمبر الى يناير أو فبراير • و أقل تعداد الفي

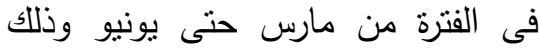
على جميع الاصناف المختبرة فى جميع لئى وني المحافظات. - عموما لايوجد تأثثر معنوى لدرجة الحرارة والرطوبة النسبية على تعداد الحلم.

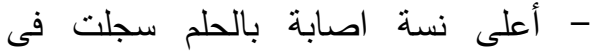
محافظة الثرقية وأقلها فى الاسماعيلية.

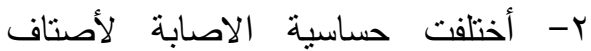

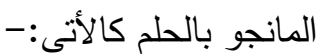




$$
\begin{aligned}
& \text { بينما لا يوجد أى نأثثر واضح لمحتوى -أصناف منوسطة الحساسية:- عويس- } \\
& \text { الفينول بالنسبة لصفة المقاومة فيما سكرى أبيض- سكرى ممتاز - تيمور }
\end{aligned}
$$

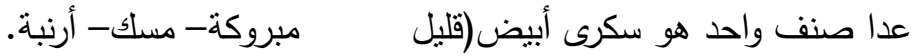

$$
\begin{aligned}
& \text { الحساسية). أصناف شديدة المقاومة :- زبلدة. } \\
& \text { ع - أختلفت شدة الأصابة بمرض التشوة فى - أظهر التحليل الأحصائى أن العلاقة بين } \\
& \text { أصناف المانجو كالأتى:- } \\
& \text { - أصناف شديدة الحساسية:- كوبانية- علاقة سلبية حيث أن الصنف زبدة شديد }
\end{aligned}
$$

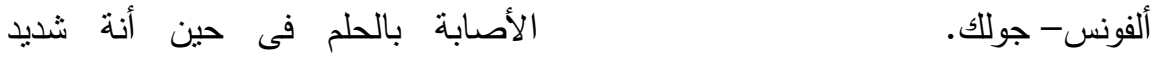

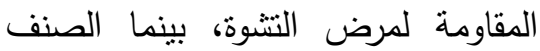

$$
\begin{aligned}
& \text { كوبانية متوسط الأصابة بالحلم فى حين لهن } \\
& \text { أنة شديد الأصابة بمرض النهوة النتوة }
\end{aligned}
$$

